\title{
IPTEKS PELAKSANAAN PEMUNGUTAN PAJAK AIR PERMUKAAN PADA CABANG PELAYANAN PENDAPATAN DAERAH WILAYAH KABUPATEN BANDUNG BARAT
}

\author{
Dhifa Buntuan ${ }^{1}$, Heince Wokas ${ }^{2}$ \\ ${ }^{1,2}$ Jurusan Akuntansi, Fakultas Ekonomi dan Bisnis Universitas Sam Ratulangi, Jl. Kampus Unsrat, Manado, \\ 95115, Indonesia \\ E-mail : dhifa_buntuan@yahoo.com
}

\begin{abstract}
The process of collecting surface water tax, hereinafter abbreviated as APER, must basically be carried out in accordance with the procedures stipulated under Regional Regulations. One from many types of local tax that included in Regional Original Income (PAD) is Surface Water Tax, which is one of the sources of finance for government and regional development to improve the welfare of the community. The procedure of collecting surface water tax is directly carried out at the Regional Revenue Service Branch (CPPD) of West Java Province, West Java Regency that is in cooperation with the One Stop Integrated Service and Capital Licensing Service (DPMPTSP) and Water Resources Management Agency (PSDA). In the implementation process, starting from the process of stipulating the Water Taking Permit (SIPPA) for new Taxpayers, registering and conducting data collection, submission, Water Acquisition Value (NPA) to Dispenda, Reporting and Regional Tax Return (SPPD), tax determination, provision tax, the distribution of the Regional Tax Assessment Letter (SKPD) to the Company for billing, and then the taxpayer makes a payment transaction. From the results of this study, the authors suggested that the Regional Revenue Service Unit of West Java Regency Padalarang, have to provide the direction and give counseling to the taxpayers both directly or indirectly to taxpayers who use and take surface water without causing damage for the environment.
\end{abstract}

Keywords: The Process Of Collecting Surface Water Tax

\section{PENDAHULUAN}

Di negara berkembang seperti Indonesia, pajak adalah salah satu bentuk penerimaan terbesar bagi Pendapatan ASli Daerah (PAD) dan merupakan sumber penerimaan terbesar. Untuk itu, proses serta prosedur dalam pelaksanaan pemungutan pajak mempunyai peran sangat penting pada penerimaan pajak daerah. Pajak air permukaan adalah salah satu pajak yang dipungut pemerintah daerah kepada pihak- pihak yang berkepentingan seperti badan usaha. Pajak air permukaan diatur dalam Peraturan Daerah Nomor 6 Tahun 2001. Perpajakan dan pendapatan daerah ditangani secara terpisah dari lingkungan keuangan berdasarkan SK Gubernur Prov. Jawa Barat Nomor 219/PO/OM/SK/71 yang dikeluarkan pada tanggal 25 September 1971 yang membentuk jawatan Perpajakan dan Pendapatan Prov. Jawa Barat. Secara efektif jawatan ini dilaksanakan pada tahun penganggaran 1972/1973. Pembayaran pajak dilakukan ke kantor kas daerah pemegang kas khusus penerima, pada Cabang Pelayanan Pendapatan Daerah (CPPD). Dalam pelaksanaan pemungutannya, setiap wajib pajak yang memanfaatkan air permukaan harus memiliki Surat Ijin Pengambilan dan Pemanfaatan Air (SIPPA). Kemudian wajib pajak mengetahui nilai perolehan air (NPA) maka akan dikeluarkan Surat Ketetapan Pajak Daerah (SKPD) untuk menentukan besarnya penagihan pajak. 


\section{TINJAUAN PUSTAKA}

Pajak Daerah. Pajak daerah menurut Undang - Undang Nomor 28 Tahun 2009 tentang Pajak Daerah dan Retribusi pasal 1 ayat 10 adalah kontribusi wajib kepada daerah yang terutang oleh orang pribadi atau badan usaha yang bersifat memaksa berdasarkan Undang - Undang, dengan tidak mendapatkan imbalan secara langsung dan digunakan untuk keperluan Daerah bagi sebesar-besarnya kemakmuran rakyat. Dalam pemungutan pajak daerah terdapat subjek dan objek pajak. Menurut Marihot P Siahaan (2005:56), subjek pajak daerah yaitu wajib pajak orang pribadi maupun badan yang dapat dikenakan pajak daerah. Sementara objek pajak menurut Santoso Brotodiharjo (2011:86) adalah manifestasi dari (keadaan yang nyata). Maksudnya yaitu keadaan atau peristiwa berdasarkan aturan perpajakan dapat dikenakan pajak.

Tarif Pajak Daerah. Perhitungan pajak adalah salah satu unsur penting dalam menentukan besarnya pajak yang terutang yang harus dibayarkan oleh wajib pajak. Tarif pajak daerah diatur dalam Undang-Undang Nomor 28 Tahun 2009 tentang Pajak daerah dan Retribusi Daerah dengan pembatasan tarif paling tinggi berbeda dalam tiap jenis pajak. Contoh Pajak Air Permukaan ditetapkan paling tinggi sebesar 10\% atau pajak yang berasal dari rokok yang paling tertinggi yaitu $10 \%$ dari cukai rokok.

Pemungutan Pajak Daerah. Pada pelaksanaanya, pemungutan pajak daerah berdasarkan aturan UU No 28 Tahun 2009 tentang pajak daerah dan retribusi daerah tidak dapat diborongkan. Maksudnya adalah bahwa semua proses pemungutan pajak itu tidak bisa diberikan secara langsung ke pihak ketiga. Akan tetapi boleh menjalin kerjasama dengan pihak ketiga dalam proses pemungutannya, yaitu seperti mencetak formulir pajak yang dibutuhkan, mengirimkan surat kepada (WP), atau menghimpun data objek pajak dan subjek Pajak. Adapun beberapa aktifitas atau kegiatan yang tidak bisa menjalin kerjasama dengan pihak ketiga yaitu kegiatan penghitungan pajak yang terutang, penagihan dalam proses pemungutan pajak dan pengawasan penyetoran pajak. Hal ini tidak bisa dikerjasamakan karena terkait dengan dokumen-dokumen penting. Dokumen tersebut seperti Surat Pemberitahuan Pajak Daerah (SPTPD),Surat Setoran Pajak Daerah (SSPD), Dan Surat Ketetapan Pajak Daerah (SKPD). (SPTPD) atau Surat Pemberitahuan Pajak Daerah merupakan surat digunakan oleh WP untuk melaporkan penghitungan ataupun pembayaran pajak, objek atau bukan objek pajak, kewajiban dan harta sesuai ketentuan Undang -Undang perpajakan daerah. Sedangkan Surat Setoran Pajak Daerah (SSPD) yaitu merupakan bukti pembayaran yang sah yang sudah dibayarkan dengan mengisi formulir, atau sudah dibayarkan dengan cara yang lain ke kas daerah melalui berbagai tempat pembayaran yang diputuskan oleh Kepala Daerah. Kemudian (SKPD) atau Surat Ketetapan Pajak Daerah merupakan surat ketetapan pajak yang menentukan seberapa besar jumlah pajak yang terutang.

\section{METODE DAN TEKNIK PENERAPAN IPTEKS}

\subsection{Metode Penerapan Ipteks}

Agar tujuan pengabdian ini dapat tercapai diperlukan metode yang tepat dalam penerapan ipteks. Dalam hal ini menggunakan metode deskriptif dari data-data yang penulis dapatkan di tempat pengabdian.

\subsection{Teknik Penerapan Ipteks}

Teknik penerpan ipteks adalah dengan mengumpulkan data-data terkait agar dapat memberikan gambaran keadaan objek pengabdian, kemudian dilakukan analisis pelaksanaan pemungutan pajak air permukaan. 


\section{PEMBAHASAN}

\subsection{Gambaran Objek Penerapan Ipteks}

Kantor Cabang Pelayanan Pendapatan Daerah Wilayah Kabupaten Bandung Barat merupakan kantor cabang Badan Pendapatan Daerah Jawa Barat yang melayani pembayaran Pajak Kendaraan Bermotor (PKB), Bea Balik Nama Kendaraan Bermotor I dan II (BBNKB) serta Pajak Air Permukaan (APER). Dalam melaksanakan tugasnya, Kantor Cabang Pelayanan Pendapatan Daerah Wilayah Kabupaten Bandung Barat memiliki 16 wilayah kerja yaitu : Kec. Cipendeuy, Kec. Cisarua, Kec. Parongpong, Kec. Sindangkerta, Kec. Lembang, Kec. Cililin, Kec. Batujajar, Kec. Rongga, Kec. Cipatat, Kec. Cipongkor, Kec. Ngamprah, Kec. Cihampelas, Kec. Padalaraang, Kec. Cikalongwetan, Kec. Saguling, Kec. Gununghalu. CPPD mempunyai tugas pokok yaitu menyelenggarakan pengkajian kebijakan teknis bidang pelayanan pendapatan, menyelenggarakan sebagian tugas teknis operasional Badan yang merupakan urusan pemerintahan Daerah Provinsi di bidang pelayanan pendapatan, meliputi aspek pendataan dan penetapan, penerimaan dan penagihan, serta melaksanakan pelayanan administrasi dan pelayanan publik sesuai dengan tugas pokok dan fungsi CPPD.

\subsection{Pembahasan}

Proses Pemungutan Pajak Air Permukaan. Menurut PP RI Nomor 91 Tahun 2010

Tentang Jenis Pajak Daerah yang Dipungut Berdasarkan Penetapan Kepala Daerah atau Dibayar Sendiri oleh Wajib Pajak. Dengan kata lain sistem pemungutan Pajak Air Permukaan adalah Official Assesment System yaitu sistem yang pemungutan pajaknya diserahkan kepada pemerintah sebagai petugas pajak dalam memnentukan pajak terhutang wajib pajak. Berikut adalah proses pemungutan yang ada pada Kantor Cabang :

1. Pendaftaran. Orang Pribadi atau Badan yang menggunakan, memanfaatkan air permukaan harus mendaftarkan diri sebgai wajib pajak dan harus mendapatkan izin atas pemanfaatan atau penggunaan air permukaan dari dinas yang terkait yaitu Dinas Pelayanan Modal dan Perizinan Terpadu Satu Pintu (DPMPTSP) dan Dinas Pengelolaan Sumber Daya Air (PSDA). Setelah melakukan pendaftaran, wajib pajak mendapatkan Surat Izin Pengambilan dan Pemanfaatan Air (SIPPA). Setelah mendapatkan SIPPA, dapat dihitung volume penggunaan air permukaan dan Harga Dasar Air (HDA) untuk dijadikan sebagai dasar perhitungan Nilai Perolehan Air (NPA).

2. Pendataan. Pendataan potensi wajib pajak dominan dilakukan oleh Dinas Pengelolaan Sumber Daya Air (PSDA). Kantor Cabang tidak terlalu ikut berpartisipasi dalam proses pendataan. Pendataan meliputi mencari subjek dan objek pajak air permukaan. Kantor Cabang Pelayanan Pendapatan Daerah Wilayah Kabupaten Bandung Barat langsung menerima data wajib pajak yang telah dihitung Nilai Perolehan Air (NPA)-nya oleh PSDA.

3. Perhitungan dan Penetapan. Kantor Cabang Pelayanan Pendapatan Daerah Wilayah Kabupaten Bandung Barat melakukan penetapan dengan mengeluarkan Surat Ketetapan Pajak Daerah (SKPD) atas dasar Nilai Perolehan Air (NPA). NPA tersebut dihitung dan dibuatkan daftar berdasarkan masing-masing wajib pajak lalu dikirim oleh PSDA ke bagian petugas penaksir pajak. Lalu, petugas mencetak SKPD yang berisi jumlah atau total pajak yang harus dibayarkan oleh wajib pajak yang ditandatangani oleh Kepala Cabang atas nama Kepala Badan dikirimkan kepada masing-masing wajib pajak oleh petugas. Berikut adalah gambaran perhitungan yang ada pada SKPD : 
Tabel 1. Contoh Perhitungan

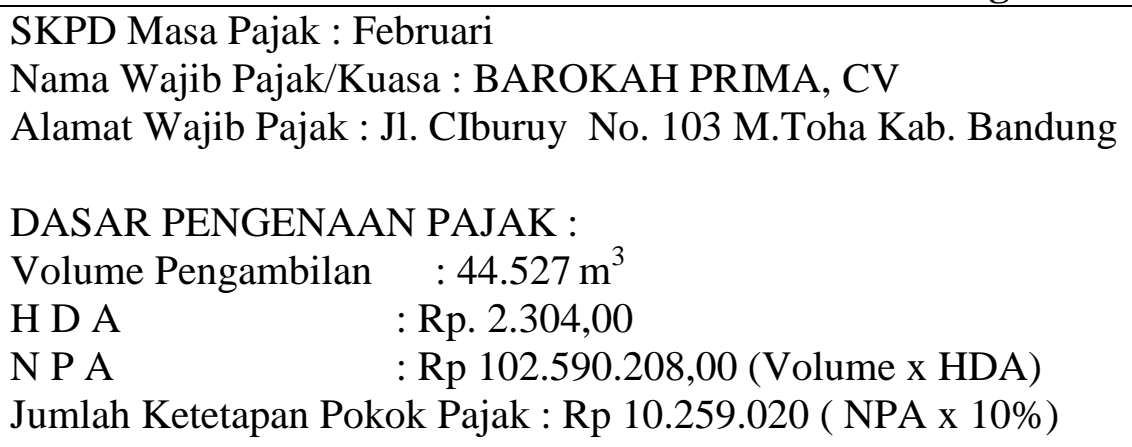

Sumber : Cabang Pelayanan Pendapatan Daerah Provinsi Wilayah Kabupaten Bandung Barat

SKPD tersebut harus segera dibayar atau dilunasi paling lambat 30 hari setelah ditetapkan, jika melebihi jatuh tempo maka akan dikenakan denda atau sanksi $2 \%$ (dua persen) perbulan dihitung setelah tanggal jatuh tempo paling lama selama 24 bulan.

4. Pembayaran dan Penyetoran. Pembayaran jumlah atau total pajak yang harus dilunasi oleh wajib pajak berdasarkan SKPD yang diterima, dapat dibayarkan di Kantor Cabang kepada Bendahara Penerimaan Pembantu secara tunai atau menggunakan giro/cek atau transfer melalui bank yang ditunjuk untuk mengelola keuangan daerah yaitu Bank BJB. Pembayar pajak harus dilakukan secara lunas. Jika wajib pajak telah membayar pajak sesuai dengan yang tercantum dalam SKPD, maka wajib pajak akan mendapatkan bukti pembayaran. Bendahara Penerimaan Pembantu harus menyetorkan ke Kas Daerah paling lama 1x24 jam dengan menggunakan Surat Tanda Setoran (STS).

Hambatan dalam Proses Pemungutan Pajak Air Permukaan. Hambatan yang terjadi selama proses pemungutan Pajak Air Permukaan pada Kantor Cabang Pelayanan Pendapatan Daerah Wilayah Kabupaten Bandung Barat :

1. Wajib pajak yang belum memiliki atau memperpanjang SIPPA, namun menggunakan atau memanfaatkan air permukaan. Sehingga PSDA tidak dapat wewenang menghitung NPA dari penguunaan air permukaan tersebut dan Kantor Cabang yang perhitungannya bergantung pada PSDA tidak dapat memungut pajaknya karena PSDA tidak mendapatkan NPA sebagai dasar perhitungan pajaknya. Wajib pajak tidak memiliki atau belum memperpanjang SIPPA beralasan karena proses pengurusannya yang panjang dan tersentralisasi. Proses tersebut membuat wajib pajak mengurungkan niatnya untuk mengurus SIPPA.

2. Wajib pajak yang tidak melapor jika sudah tidak melakukan kegiatan memanfaatkan air permukaan juga dapat menghambat proses karena akan ada perbedaan data antara wajib pajak dan fiskus. Contohnya ketika suatu perusahan tidak menggunakan air permukaan lagi yaitu karena pailit atau memang sudah tidak memerlukan lagi penggunaan air permukaan tersebut.

3. Tingkat kesadaran wajib pajak akan membayar pajak yang kurang, sehingga wajib pajak terus terlambat atau menunda pembayaran pajak.

\section{KESIMPULAN DAN SARAN}

\subsection{Kesimpulan}

Kesimpulan dari penerapan ipteks ini adalah bahwa proses yang terjadi di lapangan tidak selalu berjalan lancar dan adanya hal yang tidak sesuai dengan teknis yang ditentukan, namun masih mengacu pada aturan yang ditetapkan. Seperti pada proses pendaftaran dan pendataan. Hambatan yang terjadi selama proses pemungutan terjadi juga pada Kantor 
Cabang lainnya. Hambatan yang paling utama dari proses pemungutan adalah tingkat kesadaran Wajib Pajak sendiri akan kewajibannya membayar pajak, melaporkan dan mendaftarkan izin pemakaian atau pemanfaatan air permukaan. Padahal pajak masih menjadi penyumbang terbesar dalam kontribusi pembangunan insfratuktur, pendidikan dan kesehatan masyarakat yaitu sekitar $73 \%$.

\subsection{Saran}

Saran atas penerapan ipteks ini adalah sebagai berikut :

1. Pihak kantor cabang juga PSDA harus melakukan usaha lebih, atau alternatif usaha lain yang memudahkan untuk meningkatkan kesadaran Wajib Pajak Air Permukaan agar selalu rutin memperpanjang SIPPAnya atau agar mendaftarkan SIPPAnya jika akan memanfaatkan atau menggunakan air permukaan. Selain itu, adanya tindakan tegas dari pemerintah untuk mengeluarkan peraturan yang mengatur mengenai sanksi yang diberikan kepada wajib pajak yang melanggar tersebut.

2. Mempersingkat proses pengurusan admnistrasi agar wajib pajak tidak malas melakukan prosesnya dan rutin melakukan kewajibannya.

\section{DAFTAR PUSTAKA}

Peraturan Presiden Republik Indonesia Nomor 91 Tahun 2010 Tentang Jenis Pajak Daerah yang dipungut Berdasarkan Penetapan Kepala Daerah atau Dibayar Sendiri oleh Wajib Pajak.

Keputusan Gubernur jawa barat nomor 65 tahun 2002 tentang tugas pokok, fungsi, dan rincian tugas pada unit pelaksana teknis dinas di lingkungan Dinas Pendapatan Provinsi Jawa Barat. Pemerintah Provinsi Jawa Barat.

Peraturan Daerah Provinsi Jawa Barat Nomor 13 Tahun 2011 Tentang Pajak Daerah.

Peraturan Gubernur Jawa Barat Nomor 13 Tahun 2013 Tentang Petunjuk Pelaksanaan Peraturan Pajak Daerah untuk Jenis Pungutan Pajak Air Permukaan.

Undang-Undang No. 16 Tahun 2007 Tentang Ketentuan Umum dan Tata Cara Perpajakan. Undang-Undang Nomor 28 Tahun 2009 Tentang Pajak Daerah dan Retribusi Daerah.

Mansur, Ahmad. 2013. Pelajaran Bahasa Indonesia dan Teknik Penulisan Ilmiah, Bandung: Prima Dewi.

Mardiasmo,2003. Perpajakan (edisi revisi).Jakarta : Andi.

Siahaan, Pahala, Marihot P,S.E. 2005. Pajak dan Retribusi Daerah, Jakarta: Rajawali Pers. Kodoatie,R.J.dkk. 2001. Pengelolaan Sumber Daya Air dalam Otonomi Daerah, Yogyakarta Samudra, A. Azhari. 2015. Perpajakan di Indonesia. Jakarta: Raja Grafindo Persada Peraturan Daerah Provinsi Jawa Barat Nomor 6 Tahun 2001 tentang Pajak Pengambilan dan Pemanfaatan Air Permukaan Dinas Pendapatan Provinsi Jawa Barat.

Resmi, Siti. 2014. Perpajakan:Teori dan Kasus. Edisi ke-8. Buku 1. Jakarta: Salemba Empat. 